\title{
Characterization of Fresh and Durability Properties of Different Lime Mortars for Being Used as Masonry Coatings in the Restoration of Ancient Constructions
}

\author{
Fernando G. Branco $^{1}\left(\mathbb{D}\right.$, , Maria de Lurdes Belgas ${ }^{2} \mathbb{D}$, Cátia Mendes ${ }^{3}$, Luís Pereira ${ }^{1}$ (D) and José Marcos Ortega ${ }^{4, * \mathbb{D}}$ \\ 1 ISISE, Department of Civil Engineering, University of Coimbra, 3030-788 Coimbra, Portugal; \\ fjbranco@dec.uc.pt (F.G.B.); lfmpereira@uc.pt (L.P.) \\ 2 ISISE, Departamental Unit of Engineering, Instituto Politécnico de Tomar, 2300-313 Tomar, Portugal; \\ lbelgas@ipt.pt \\ 3 Instituto Politécnico de Tomar, 2300-313 Tomar, Portugal; cmendes@ipt.pt \\ 4 Departamento de Ingeniería Civil, Universidad de Alicante, 03080 Alacant/Alicante, Spain \\ * Correspondence: jm.ortega@ua.es; Tel.: +34-96-5903-400 (ext. 2470)
}

Citation: Branco, F.G.; Belgas, M.d.L.; Mendes, C.; Pereira, L.; Ortega, J.M. Characterization of Fresh and Durability Properties of Different Lime Mortars for Being Used as Masonry Coatings in the Restoration of Ancient Constructions.

Sustainability 2021, 13, 4909.

https://doi.org/10.3390/su13094909

Academic Editor: Antonio Caggiano

Received: 28 February 2021

Accepted: 20 April 2021

Published: 27 April 2021

Publisher's Note: MDPI stays neutral with regard to jurisdictional claims in published maps and institutional affiliations.

Copyright: (c) 2021 by the authors. Licensee MDPI, Basel, Switzerland. This article is an open access article distributed under the terms and conditions of the Creative Commons Attribution (CC BY) license (https:/ / creativecommons.org/licenses/by/ $4.0 /)$.

\begin{abstract}
Coatings and plasters are an integral part of masonry cladding, having a fundamental protective and aesthetic function. They are exposed to numerous aggressive actions, which produce their degradation over time. The utilization of lime, as a binder in masonry lining mortars, plays an important role in their durability and conservation. The objective of this work is to analyze the fresh and durability properties of lime-based mortars for their application in the restoration of old buildings. Four different kinds of mortars were studied with similar workability, using as binders lime putty, aerial lime, and hydraulic lime. The aggregates used consisted of sand and crushed rock powder. As fresh properties, the consistency (by using the flow table) and water retentivity were determined. With respect to durability-related properties, water absorption by capillarity and by immersion, drying kinetics, and carbonation depth were studied. Bulk density and porosity of the mortars were also obtained. Mortars with lime putty showed higher global porosity and water absorption by immersion, while aerial lime mortars presented lower porosity and higher water absorption by capillarity. Finally, the durability performance of all the studied lime mortars was overall adequate for being applied as masonry coatings in the restoration of old buildings.
\end{abstract}

Keywords: coatings; plasters; mortars; lime putty; aerial lime; hydraulic lime; crushed rock powder; durability; masonry; rehabilitation

\section{Introduction}

Since ancient times, mortars have been used in construction elements. Among the different binders used in mortars, one of the oldest is lime [1,2]. At present, one of the most important problems registered for construction is the lack of conservation, maintenance, and rehabilitation interventions. These problems result in the degradation of old buildings and abandonment of ancient heritage. In this line, it is interesting to emphasize the importance of the rehabilitation of buildings from an environmental point of view [3-5] because with these maintenance and rehabilitation interventions, it is possible to increase their service life. In addition, the rehabilitation of buildings would also contribute to reducing the wastes produced by their demolition, as well as the possible $\mathrm{CO}_{2}$ emissions produced along the construction process of the new stand-in buildings, contributing to sustainability in that way. In several countries, rehabilitation works in existing buildings have experienced an important increase over the past few decades. Therefore, it is necessary to evaluate the compatibility of modern building materials with the original ones since harmful by-products may induce severe damage to old materials, such as stone blocks [6,7].

Regarding the lime-based mortars, their utilization as a binder in coatings and plasters plays an important role in the durability and conservation of buildings. In addition to 
this, their use has become very popular in the rehabilitation works of historic masonry. Therefore, research has been developed in relation to the compatibility of lime with different binders [8]. In relation to the use of blended lime-cement mortars to substitute lime mortars, there are several authors $[9,10]$ who pointed out that the incorporation of cement can affect the performance of the mortars, recommending the use of binders that combined different types of limes [9], such as aerial and hydraulic lime [11,12], or limiting the content of cement in the binders [10]. There are also studies in which new additions have been assessed for being incorporated in blended lime mortars, such as that carried out by Aalil et al. [13], who studied mortars produced using aerial lime, sand, and brick dust.

The microstructure of the lime mortars plays an important role in their durability and mechanical behavior [14,15]. In this regard, Santos et al. [14] studied the pore structure of air lime mortars prepared with different aggregates, revealing a relationship between their mechanical properties and microstructure. In addition to this, Aggelakopoulou et al. [15] analyzed several mortars made with lime putty and hydrated lime powder, obtaining as a result that lime powder mortars exhibited a unimodal pore size distribution, whereas lime putty mortars presented a bimodal one. The durability of lime mortars in aggressive environments is today a relevant research issue, and to characterize the durability-related properties of these mortars, it is also necessary to ensure the compatibility of old and new restoration materials [16]. With respect to this topic, it is worth highlighting the works of Grilo et al. [17,18], who evaluated the mechanical, physical, and microstructural behavior of mortars formulated with natural hydraulic lime, subject to natural marine environments, and humid and standardized conditions, obtaining positive results at young ages [17] and pointing out the influence of the curing conditions of the mortars [18].

For selecting mortars for rehabilitation of old constructions, the characteristics of existing masonry should be considered [19]. The deformability of the mortars must be similar to that of the masonry substrate and the water vapor permeability. In addition, the resistance of the mortar should not be higher than the resistance of the masonry substrate [20]. To verify the compatibility, it is interesting to determine the behavior of the mortars for being used in the rehabilitation works [16], especially regarding their durability and physical characteristics [2], and their mechanical performance [21].

Therefore, the objective of the present research is to analyze the fresh and durability properties of lime-based mortars for being used in the restoration of old buildings. Four different kinds of mortars were studied with similar workability, using as binders lime putty, aerial lime, and hydraulic lime. Sand and crushed rock powder were used as aggregates. Two different curing conditions were established. The analyzed fresh properties of the mortars were the consistency (by using the flow table) and water retentivity. Regarding the durability-related parameters, water absorption by capillarity, water absorption by immersion, drying kinetics, and carbonation depth were studied. Finally, the bulk density and porosity of the mortars were also determined.

The results obtained for all variables are described, analyzed, and reviewed. The results are also compared with results from a previously published bibliography. The adequacy of the studied mortars for use as masonry coatings and plasters in the rehabilitation of old constructions is addressed in view of the results obtained.

\section{Materials and Methods}

\subsection{Materials}

The binders used for preparing the mortars were aerial lime, hydraulic lime, and lime putty. They were combined with two different aggregates, river sand, and crushed rock powder.

With respect to the limes used, the aerial lime was provided by the manufacturer Calcidrata de Alcanede-Santarém (Portugal), being classified as CL90 according to NP EN 459-1 [22]. On the other hand, the company Aldeias de Pedra Construções, Lda (Vila de Rei, Portugal) supplied the lime putty. Lastly, the hydraulic lime used was classified as HL5 [22], and it was provided by the company Cimpor (Lisbon, Portugal). 
In relation to the aggregates used for preparing the mortars, the river sand was supplied by the company José Antunes \& Filhos, Lda (Carvalhal-Sertã, Portugal) and extracted from its quarry of Sociedade Extração Areia do Tejo (SEAT) placed in GuerreiraSanta Cita (Santarém; Portugal). The company Mota Engil provided the crushed rock powder from its quarry sited in Vale dos Ovos-Sabacheira (Portugal). Prior to the setting of the samples, both river sand and crushed rock powder were passed through a sieve with $4 \mathrm{~mm}$ mesh.

The particle size distributions for both aggregates, obtained according to the standard NP EN 933-1 [23], are depicted in Figure 1. Their density, bulk density, maximum $\left(\mathrm{D}_{\max }\right)$, and minimum $\left(\mathrm{d}_{\mathrm{min}}\right)$ diameters are compiled in Table 1 . The density of both aggregates was obtained following the standard NP EN 1097-6 [24], while their bulk density was determined according to the standard NP EN 1097-3 [25].

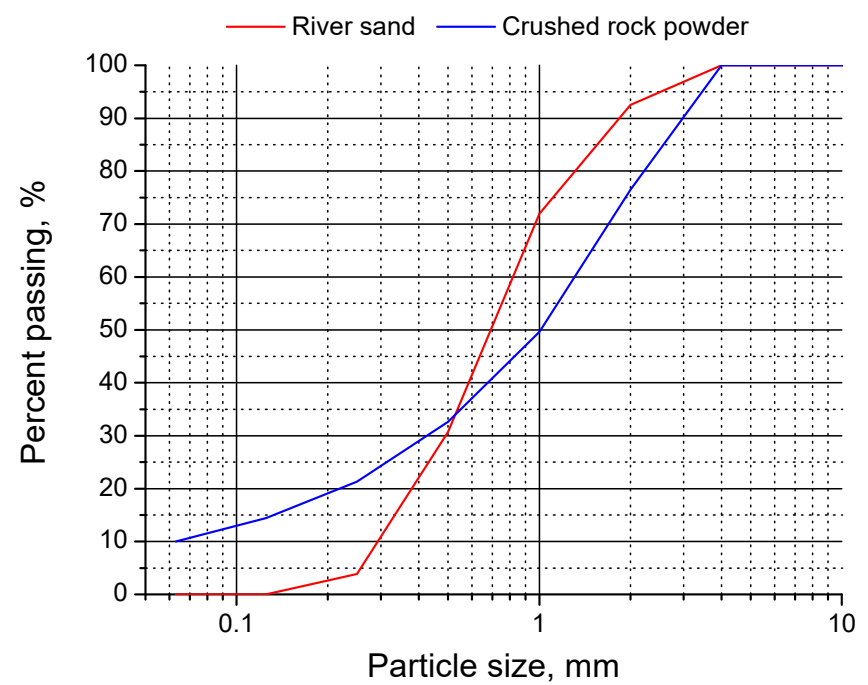

Figure 1. Particle size distributions obtained for river sand and crushed rock powder.

Table 1. Densities and diameters for riversand and crushed rock powder.

\begin{tabular}{ccccc}
\hline & $\begin{array}{c}\mathbf{D}_{\text {max }} \\
(\mathbf{m m})\end{array}$ & $\begin{array}{c}\mathbf{d}_{\text {min }} \\
(\mathbf{m m})\end{array}$ & $\begin{array}{c}\text { Density } \\
\left(\mathbf{k g} / \mathbf{m}^{\mathbf{3}}\right)\end{array}$ & $\begin{array}{c}\text { Bulk Density } \\
\left(\mathbf{k g} / \mathbf{m}^{\mathbf{3}}\right)\end{array}$ \\
\hline $\begin{array}{c}\text { Sand } \\
\begin{array}{c}\text { Crushed rock } \\
\text { powder }\end{array}\end{array}$ & 2 & 0.250 & 2609 & 1494 \\
\hline
\end{tabular}

\subsection{Sample Preparation and Curing Conditions}

The main potential application of the lime mortars analyzed in this research is for being used as masonry coatings or plasters in the restoration of old and ancient constructions, including historical or heritage buildings.

Four series of mortars have been tested in this work. The first series was made using lime putty as binder and river sand as aggregate and named ASPL. A mortar combining aerial and hydraulic limes in the binder, together with sand as aggregate, was also studied, designed as ACL/HL. Furthermore, other mortar with only aerial lime as the binder, but containing two aggregates (sand and crushed rock powder) was prepared and named ACL/PP. The last mortar studied (ASPL/PP series) also incorporated the above-mentioned two aggregates, but the binder used only consisted of lime putty.

For all the mortars, the binder to aggregate ratio was 1:3 in volume. This ratio has been chosen because it is one of the most common values used for the feature application of these mortars, as coatings and plasters for restoration of old constructions [2]. The aim of this work is to study mortars with the same or very similar workability in order to facilitate their real practical use. Therefore, the amount of water used for setting each one of the 
mortar series was established according to the previously mentioned criterion, consisting of all the mortars produced had the same or very similar workability, independent of their composition. The final dosages in mass for each one of the series are compiled in Table 2.

Table 2. Dosages in mass for the different mortar series analyzed.

\begin{tabular}{cccccccc}
\hline $\begin{array}{c}\text { Mortar } \\
\text { Series }\end{array}$ & $\begin{array}{c}\text { Aerial Lime } \\
\mathbf{( g )}\end{array}$ & $\begin{array}{c}\text { Hydraulic Lime } \\
\mathbf{( g )}\end{array}$ & $\begin{array}{c}\text { Lime Putty } \\
\mathbf{( g )}\end{array}$ & $\begin{array}{c}\text { Crushed Rock } \\
\text { Powder }(\mathbf{g})\end{array}$ & $\begin{array}{c}\text { Sand } \\
(\mathbf{g})\end{array}$ & $\begin{array}{c}\text { Water } \\
(\mathbf{m L})\end{array}$ & $\begin{array}{c}\text { Water to } \\
\text { Binder Ratio }\end{array}$ \\
\hline ASPL & - & - & 370 & - & 1380 & 88.58 & 0.24 \\
ACL/HL & 92 & 128 & - & - & 1400 & 300 & 1.36 \\
ACL/PP & 182 & - & - & 475 & 920 & 280 & 1.54 \\
ASPL/PP & - & - & 370 & 475 & 920 & 87.32 & 0.24 \\
\hline
\end{tabular}

The setting of the mortars was carried out following the standard EN 1015-2 [26], using an automatic mixer. Prismatic samples with dimensions $40 \mathrm{~mm} \times 40 \mathrm{~mm} \times 160 \mathrm{~mm}$ were made in accordance with standard EN 1015-11 [27].

Two different curing conditions were established. The first condition consisted of keeping a group of samples in a humidity chamber under an optimum condition of $20{ }^{\circ} \mathrm{C}$ temperature and $95 \%$ relative humidity $(\mathrm{RH})$ during the first seven hardening days from setting. On the other hand, in the second condition, another group of samples was exposed to a laboratory condition with $20 \pm 2{ }^{\circ} \mathrm{C}$ temperature and $50 \pm 5 \% \mathrm{RH}$ during the same initial 7 days of hardening. Once finished this 7-day curing period, all the specimens were stored in the abovementioned laboratory environment $\left(20 \pm 2{ }^{\circ} \mathrm{C}\right.$ and $50 \pm 5 \% \mathrm{RH}$ ) up to the longest testing age studied (90 days). The curing condition was incorporated to the denomination of the mortar series, in addition to their composition (binder and aggregates used) previously explained. In order to facilitate the comprehension of the results description, the meaning of these denominations are compiled in Table 3 (the samples cured in the humidity chamber incorporate the letter $C$ at the end of their designation, while those cured in the laboratory condition include the letter L after the series name).

Table 3. Summarized designation of the lime mortars studied.

\begin{tabular}{cccc}
\hline Designation of the Mortar & Binder & Aggregate & Curing Condition \\
\hline ASPL-L & Lime putty & Sand & $20^{\circ} \mathrm{C}$ and $50 \% \mathrm{RH}$ \\
ASPL-C & Lime putty & Sand & $20^{\circ} \mathrm{C}$ and $95 \% \mathrm{RH}$ \\
ACL/HL-L & Sand & $20^{\circ} \mathrm{C}$ and $50 \% \mathrm{RH}$ \\
ACL/HL-C & Aerial lime + Hydraulic lime & Sand lime + Hydraulic lime & $20^{\circ} \mathrm{C}$ and $95 \% \mathrm{RH}$ \\
ACL/PP-L & Aerial lime & Sand + Crushed rock powder & $20^{\circ} \mathrm{C}$ and $50 \% \mathrm{RH}$ \\
ACL/PP-C & Aerial lime & Sand + Crushed rock powder & $20^{\circ} \mathrm{C}$ and $95 \% \mathrm{RH}$ \\
ASPL/PP-L & Lime putty & Sand + Crushed rock powder & $20^{\circ} \mathrm{C}$ and $50 \% \mathrm{RH}$ \\
ASPL/PP-C & Lime putty & Sand + Crushed rock powder & $20^{\circ} \mathrm{C}$ and $95 \% \mathrm{RH}$ \\
\hline
\end{tabular}

\subsection{Characterization of Fresh Properties of Lime Mortars}

\subsubsection{Determination of Consistency by Using the Flow Table}

The purpose of determining the consistency of the lime fresh mortars is to assess their workability, in order to establish the best possible consistency according to the feature applications of those mortars (plasters, coatings, masonry laying, regularization of surfaces, etc.) [28].

In this work, immediately after the setting, the consistency of the studied mortars was determined using the flow table according to standard EN 1015-3 [29]. The parameters obtained from this test are the flow value and the flow percentage. Three consistency measurements were made for each one of the mortar series. 


\subsubsection{Determination of Water Retentivity}

The aim of the water retentivity test is to estimate the percentage of water that a fresh mortar is capable of retaining after a suction treatment performed under standardized conditions. This test was carried out in the fresh mortars following the procedure described in the standard EN 1015-8 [30], obtaining, as a result, the percentage of water retained. Three measurements were made for each one of the mortar series analyzed.

\subsection{Characterization of Hardened Properties of Lime Mortars}

\subsubsection{Bulk Density and Porosity}

Among other factors, the composition of the mortars, the processes used in their execution, and the way of their application in the construction elements could affect the bulk density and the porosity of the mortars [31]. In addition to this, the microstructure of materials could affect their main properties [32], such as mechanical strength, permeability, water absorption, resistance to the ingress of aggressive substances, etc. Therefore, obtaining information about the volume of pores of the lime mortars studied would be interesting.

In this work, the porosity and the bulk density of the mortars were determined according to standard NP EN 1936 [33]. The samples tested were prismatic pieces obtained from cutting the original specimens cast in molds with dimensions $40 \mathrm{~mm} \times 40 \mathrm{~mm} \times 160 \mathrm{~mm}$. For each mortar type and curing condition studied, six different samples were tested at 90 hardening days.

\subsubsection{Water Absorption by Capillarity}

One of the main important ways of ingress of aggressive substances in a construction material is through water absorption [34], especially in the case of mortar coatings and plasters $[35,36]$. Therefore, the study of this property in the analyzed lime mortars is relevant. In this research, the coefficient of water absorption by capillarity $\left(\mathrm{C}_{\mathrm{c}}\right.$ coefficient [37]) was determined by performing the test procedure described in the standard EN 1015-18 [37]. Before starting the test, the specimens were dried in a ventilated oven at a temperature of $60 \pm 5{ }^{\circ} \mathrm{C}$ until reaching a constant mass. Distilled water was used in this test. Three different prismatic samples were tested at 90 hardening days for each mortar type and curing condition studied.

\subsubsection{Water Absorption by Immersion}

The objective of the test is to evaluate the water absorption after total immersion along $48 \mathrm{~h}$ in prismatic samples with dimensions $40 \mathrm{~mm} \times 40 \mathrm{~mm} \times 160 \mathrm{~mm}$. The procedure for this test is defined in the specification E394 [38] of the National Laboratory of Civil Engineering of Portugal (formerly Laboratorio Nacional de Engenharia Civil, LNEC, Lisbon, Portugal).

Prior to immersion in distilled water, samples were dried in a ventilated oven at a temperature of $60 \pm 5{ }^{\circ} \mathrm{C}$ up to constant mass. After that, they were cooled inside a desiccator, and then, the mass of each dried sample was recorded. The next step consisted of keeping immersed the samples inside a hermetic box filled with water for $48 \mathrm{~h}$. The immersion of the samples in water must be slow and during this process, and the specimens must be inclined at approximately $45^{\circ}$ from the water surface, in order to remove the possible air bubbles still present in the material [38] (see Figure 2a). Once the samples were totally immersed, they were positioned vertically, and the test started (see Figure $2 b$ ).

After $48 \mathrm{~h}$ of water immersion, the specimens were removed and cleaned with a damp cloth, and the saturated mass of each specimen was noted. The parameter obtained with this test is the percentage of water absorption by immersion, which is calculated with the following equation:

$$
W_{48 h}=\frac{m_{2}-m_{1}}{m_{1}} \times 100
$$


where $W_{48 \mathrm{~h}}$ is the percentage of water absorption by immersion for $48 \mathrm{~h}(\%), m_{2}$ is the saturated mass of the specimen after immersion $(\mathrm{g})$, and $m_{1}$ is the mass of the dried sample before immersion $(\mathrm{g})$.

For each one of the mortar types and conditions studied, three specimens were tested at 90 hardening days.

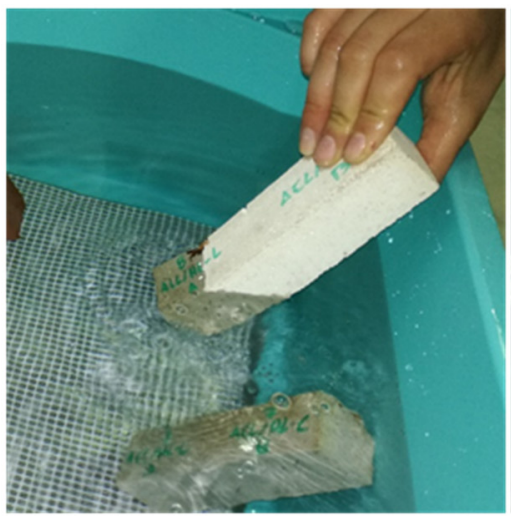

(a)

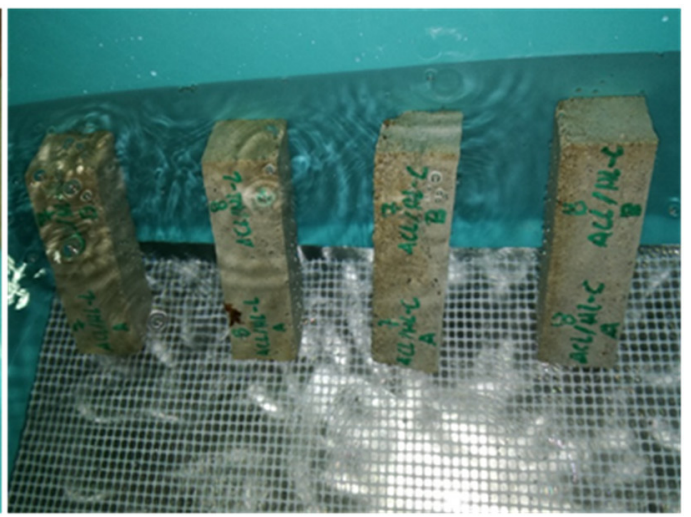

(b)

Figure 2. (a) Immersion of a sample inclined $45^{\circ}$ from the water surface and (b) samples vertically positioned after being totally immersed, being this position kept during the test progress.

\subsubsection{Drying Kinetics Assessment}

The drying kinetics evaluation test allows obtaining information about the behavior of mortars in relation to the process of internal water evaporation and their drying capacity. It is important to highlight that the study of this property is relevant because the content of internal water in the mortars has an influence on the thermal performance of the walls where they are applied as coatings or plasters.

The procedure for assessing the drying kinetics of the studied mortars was carried out according to Pavão [39] and Gomes [40]. Before starting the test, the four lateral faces of each prismatic sample were sealed with epoxy resin LR2000 manufactured by Henkel Rubson (Henkel Ibérica, Barcelona, Spain) using a brush (see Figure 3a). Two coats were applied with a time lag of $24 \mathrm{~h}$ between them (see Figure $3 \mathrm{~b}$ ). After $24 \mathrm{~h}$ of applying the last coat of resin, the samples were oven dried at $60 \pm 5{ }^{\circ} \mathrm{C}$ temperature until constant mass. Then, the samples were totally immersed in water for $48 \mathrm{~h}$ (see Figure 3c), and once finished this time period, they were removed and cleaned with a damp cloth. Immediately after, one of the base faces unsealed with resin was waterproofed using a plastic film fixed with two elastic ropes (see Figure 3d). This was performed in order to ensure that the drying process is only produced through one of the base faces of the prismatic sample, producing a unidirectional drying flow.

The initial mass of the samples was noted, and they were placed on a tray exposed to the laboratory environment $\left(20 \pm 2{ }^{\circ} \mathrm{C}\right.$ and $\left.50 \pm 5 \% \mathrm{RH}\right)$. Then, the test started and it consisted of weighting the specimens at the following times from the beginning of the test: $30 \mathrm{~min}, 1 \mathrm{~h}, 2 \mathrm{~h}, 4 \mathrm{~h}, 6 \mathrm{~h}, 24 \mathrm{~h}$, and then each $24 \mathrm{~h}$ until reaching constant mass. During the drying process, the samples were exposed to a laboratory environment $\left(20 \pm 2{ }^{\circ} \mathrm{C}\right.$ and $50 \pm 5 \% \mathrm{RH})$.

The parameter obtained with this test is the percentage of evaporated water, which is calculated with the following equation:

$$
W_{i}=\left|\frac{m_{i}-m_{0}}{m_{0}}\right| \times 100
$$

where $W_{i}$ is the percentage of evaporated water at the corresponding measurement time $(\%), m_{i}$ is the mass of the sample at the corresponding measurement time (g), and $m_{0}$ is the initial mass of the sample at the beginning of the test $(\mathrm{g})$. 
For each one of the mortar types and conditions studied, three specimens were tested at 90 hardening days.

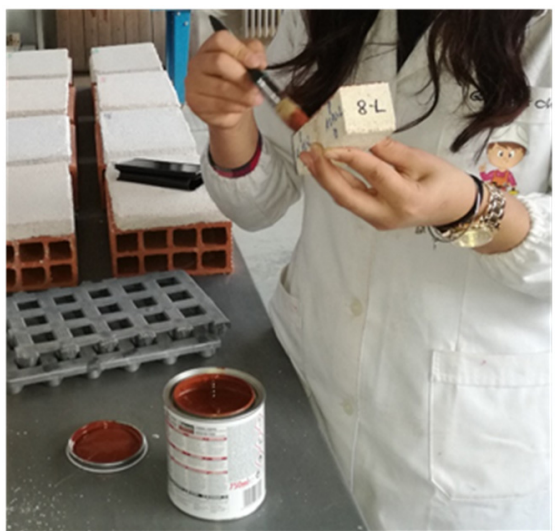

(a)



(c)



(b)

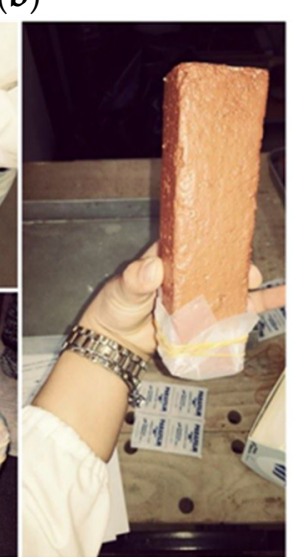

(d)

Figure 3. (a) Sealing of the lateral faces of a prismatic sample with epoxy resin using a brush; (b) samples after applying the two coats of epoxy resin; (c) one of the steps in the preparation of the test consisting of total immersion of the samples in water for $48 \mathrm{~h}$; (d) waterproofing of one of the unsealed base faces of the samples using a plastic film fixed with two elastic ropes.

\subsubsection{Carbonation Depth}

The evolution of carbonation depth in the lime mortars was determined in accordance with RILEM recommendation CPC-18 [41]. Pieces obtained from the original prismatic specimens were sprayed with a $2.5 \%$ phenolphthalein solution. The depth of the colorless carbonated part from the external surface of the sample was measured. For each mortar type and curing condition studied, six pieces taken from three different prismatic specimens were tested at 28 and 90 hardening days.

\section{Results}

\subsection{Fresh Properties of Lime Mortars}

The flow values and the flow percentages for the studied mortars are compiled in Table 4 . Those parameters were very similar for all the series. This was expected because the main criterion for establishing the dosages of the lime mortars, particularly their water-to-binder ratio, was that all of them had similar workability, independently of their composition. Despite that, the flow value and the flow percentage noted for the mortar with lime putty and both river sand and crushed rock powder as aggregates (ASPL/PP series) were slightly lower, whereas both parameters were scarce higher for the mortars, which combined aerial lime with the abovementioned both aggregates (ACL/PP series), in comparison with the other analyzed series. 
Table 4. Flow value and flow percentage results obtained for the studied lime mortars.

\begin{tabular}{ccc}
\hline Mortar Series & Flow Value $(\mathbf{m m})$ & Flow Percentage $\mathbf{( \% )}$ \\
\hline ASPL & 150 & 50 \\
ACL/HL & 150 & 50 \\
ACL/PP & 155 & 55 \\
ASPL/PP & 145 & 45 \\
\hline
\end{tabular}

Regarding the water retentivity test, the percentage of water retained for each type of mortar is depicted in Figure 4. The values of the water retained were ranging from $77 \%$ to $80 \%$, and scarce differences were observed in this parameter between the studied mortar series. It was slightly higher for mortars with aerial lime combined with sand and crushed rock powder as aggregates (ACL/PP series), while the percentage of water retained was lower for mortars, which incorporated lime putty (ASPL and ASPL/PP series).

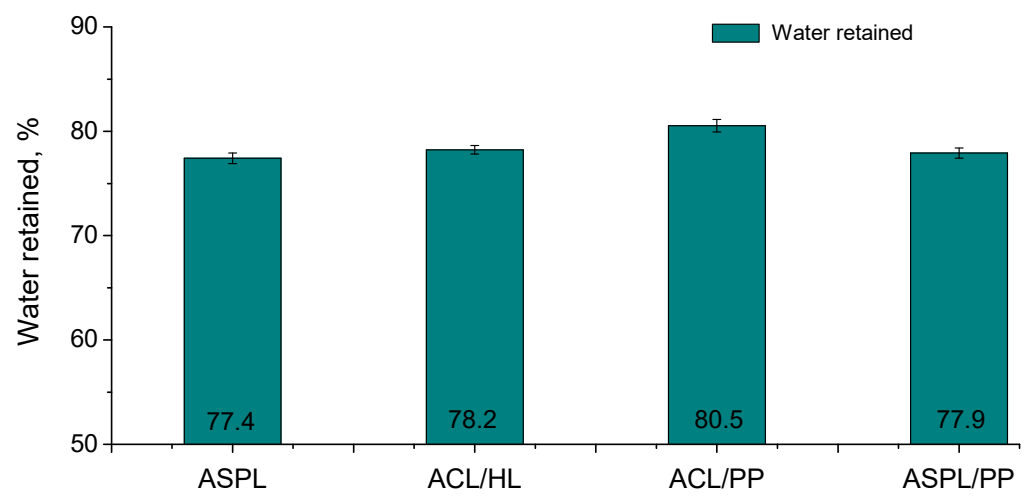

Figure 4. Percentage of water retained for the lime mortar series analyzed. In this figure and in the following is represented the mean value of the parameter obtained for each mortar type. This value is also indicated at the bottom of each bar. In addition, the error bars represent the standard deviation.

\subsection{Hardened Properties of Lime Mortars}

\subsubsection{Bulk Density and Porosity}

The bulk densities at 90 days noted for the different lime mortars and curing conditions studied are represented in Figure 5. For both curing conditions, mortars with lime putty (ASPL and ASPL/PP series) showed lower bulk densities, especially in the case of mortars with only sand as aggregate (ASPL series). On the other hand, the highest bulk density corresponded to mortars with aerial lime, sand, and crushed rock powder (ACL/PP series). For the same binder, specimens cured in the laboratory condition showed greater values of this parameter, compared to those cured in the humidity chamber, with the exception of the ASPL series. In addition to this, it is interesting to highlight that the incorporation of crushed rock powder as aggregate produced an increase in the bulk density of the mortars.

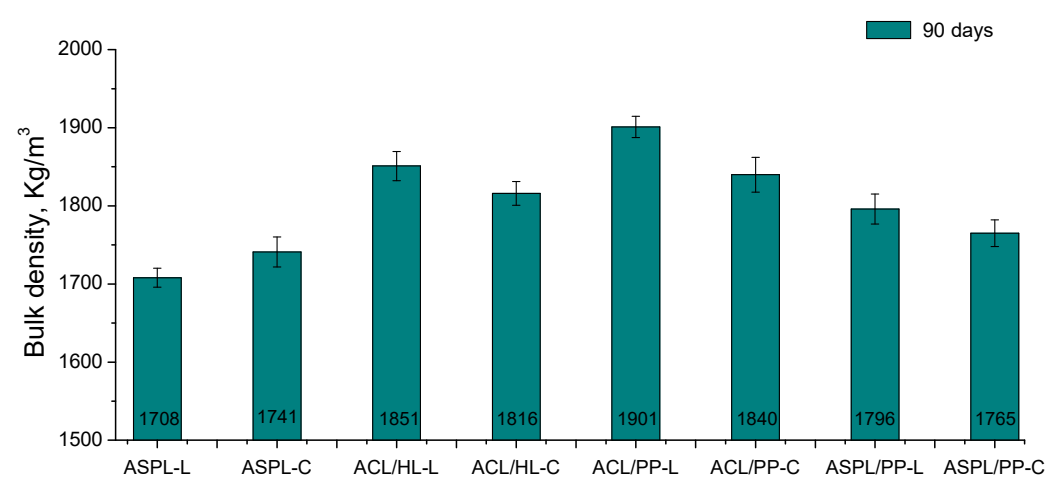

Figure 5. Results of bulk density obtained for the different series analyzed. 
The porosity results for the lime mortars can be observed in Figure 6. The specimens with lime putty (ASPL and ASPL/PP series) showed higher global porosities at 90 hardening days for both curing conditions, independently of the incorporation of crushed rock powder as aggregate. Furthermore, the series with lime putty cured in the humidity chamber (ASPL-C and ASPL/PP-C) had slightly lower porosities than those cured in the laboratory condition (ASPL-L and ASPL/PP-L). On the other hand, the values of this parameter for mortars with aerial lime (ACL/HL and ACL/PP series) were lower, compared to those made using lime putty. For the abovementioned series with aerial lime in the binder, the porosity was scarce higher when the curing is produced in the humidity chamber, in comparison with the laboratory condition.

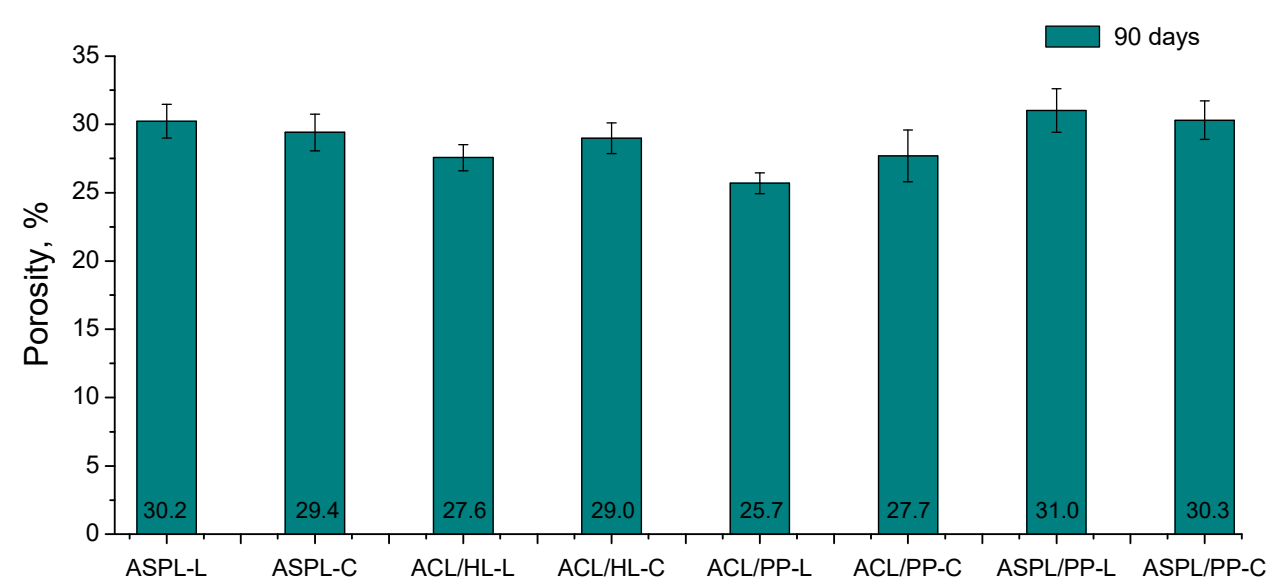

Figure 6. Porosity values noted at 90 hardening days for the lime mortars.

\subsubsection{Water Absorption by Capillarity}

The results of the coefficient of water absorption by capillarity obtained for the different lime mortars tested are shown in Figure 7. The specimens made with lime putty and sand as aggregate (ASPL-L and ASPL-C series) had the lowest values of this coefficient, followed by the other series with lime putty, which also incorporated crushed rock powder combined with sand as aggregates (ASPL/PP-L and ASPL/PP-C series). The highest coefficients of water absorption by capillarity were noted for mortars with aerial lime, without observing noticeable differences when hydraulic lime was added to the binder (ACL/HL-L and ACL/HL-C series) or when crushed rock powder was included in the mortar as aggregate (ACL/PP-L and ACL/PP-C series).

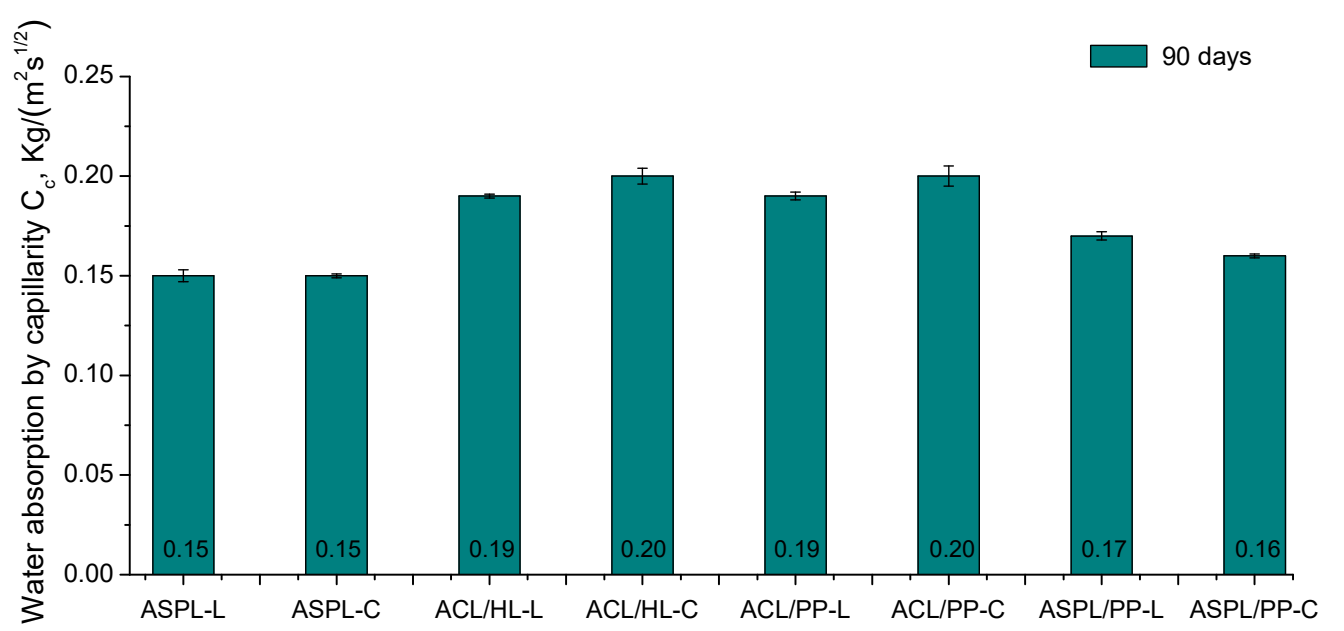

Figure 7. Results obtained for the coefficient of water absorption by capillarity in the different mortar series tested. 
Slight differences related to the curing condition were observed for each one of the mortar compositions analyzed. In general, for specimens with aerial lime higher values of the coefficient of water absorption by capillarity were obtained for samples cured in the humidity chamber (ACL/HL-C and ACL/PP-C series), compared to those cured in the laboratory condition (ACL/HL-L and ACL/PP-L series). For lime putty mortars, no effect had the curing condition in specimens with only sand as aggregate (ASPL-L and ASPL-C series), while for those with sand and crushed rock powder, the coefficient was scarce lower for specimens cured in a humidity chamber (ASPL/PP-C) than for those cured under laboratory environment (ASPL/PP-L).

\subsubsection{Water Absorption by Immersion}

The percentages of water absorption by immersion obtained for the lime mortars studied are depicted in Figure 8. The greatest values of this parameter were noted for mortars with lime putty and sand (ASPL-L and ASPL-C series), followed by those that also incorporated crushed rock powder (ASPL/PP-L and ASPL/PP-C series). In view of these results, the inclusion of crushed rock powder as aggregate in the lime putty mortars had a beneficial effect [14], producing a reduction of the water absorbed by immersion. On the other hand, the lowest values of this parameter were observed for mortars with aerial lime, with a slightly lower percentage of water absorbed by immersion for specimens that incorporated crushed rock powder as aggregate (ACL/PP-L and ACL/PP-C series), compared to those that combined aerial and hydraulic lime in the binder (ACL/HL-L and ACL/HL-C series). The percentages of water absorbed by immersion were scarce higher for each lime mortar series when the specimens were cured in a humidity chamber than in the laboratory environment. The most noticeable difference between both curing conditions was noted for mortars with aerial and hydraulic lime in the binder (ACL/HL-L and ACL/HL-C series).

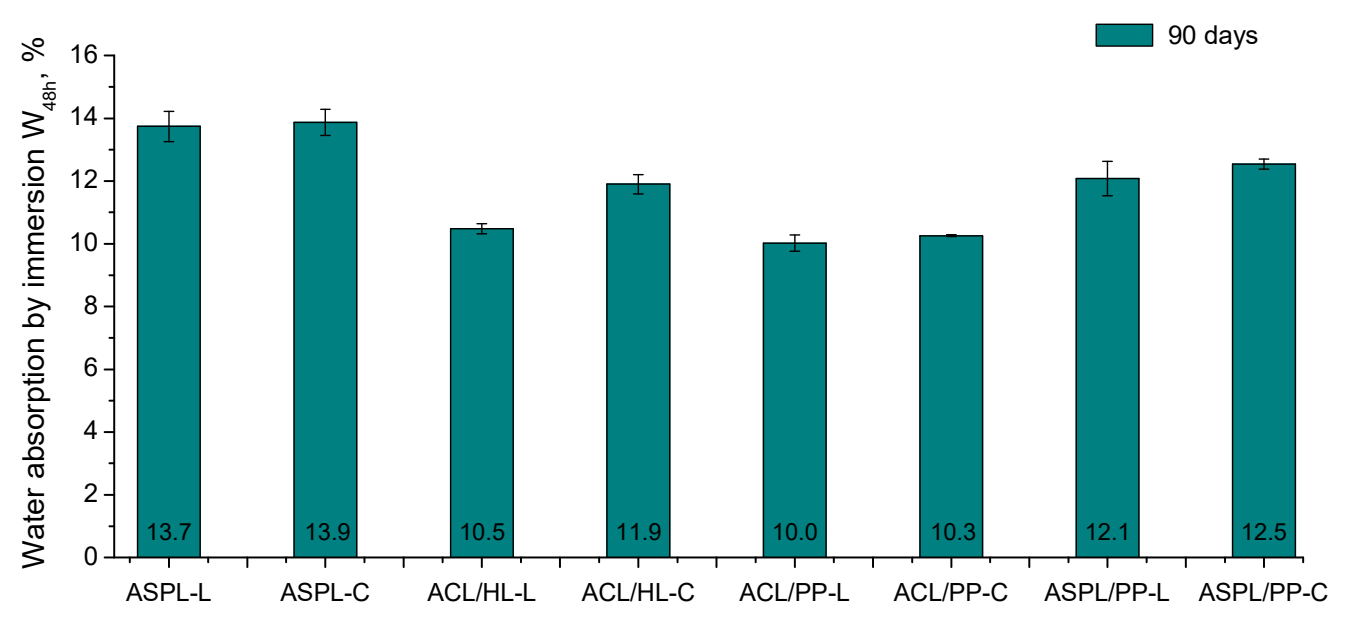

Figure 8. Percentage of water absorption by immersion for the lime mortars analyzed.

\subsubsection{Drying Kinetics Assessment}

The evolution of the percentage of evaporated water during the development of this test for the different lime mortars analyzed is represented in Figure 9. At the initial stages of the drying process, the highest percentages of evaporation were noted for ASPL/PP-C specimens, and the lowest for ACL/PP-L ones, being very similar for the rest of the tested mortar series. After long-term drying, the lowest percentages of evaporated water were observed for lime putty mortars with sand and crushed rock powder (ASPL/PP-L and ASPL/PP-C series) and for lime putty mortars with only sand as aggregate cured under laboratory environment (ASPL-L series), ranging from $6.5 \%$ to $7.5 \%$. For the other series of lime mortars, the percentages of evaporation were relatively similar, with values between $8.5 \%$ and $10 \%$. 


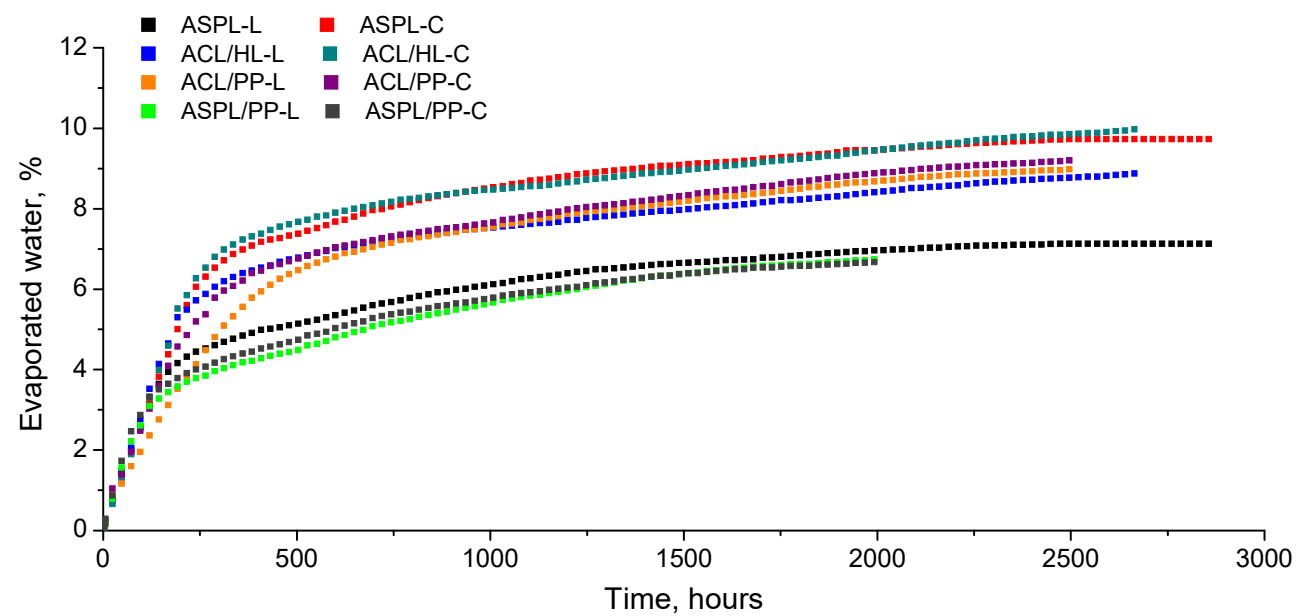

Figure 9. Evolution of the percentage of evaporated water along the drying kinetics assessment test for the lime mortars studied.

\subsubsection{Carbonation Depth}

The depths of the carbonation front at 28 and 90 hardening days for the different mortars analyzed are depicted in Figure 10. It was not reported differences in this parameter between the curing conditions for all the kinds of mortars studied. No carbonated material was observed at 28 hardening days for the majority of the series with the exception of ACL/HL mortars. On the other hand, all series showed carbonated material at 90 days. The highest carbonation depths were noted for mortars with lime putty (ASPL and ASPL/PP series), whereas the lowest corresponded to specimens with aerial lime (ACL/HL and $\mathrm{ACL} / \mathrm{PP}$ series), especially for those that incorporated crushed rock powder as aggregate (ACL/PP mortars).

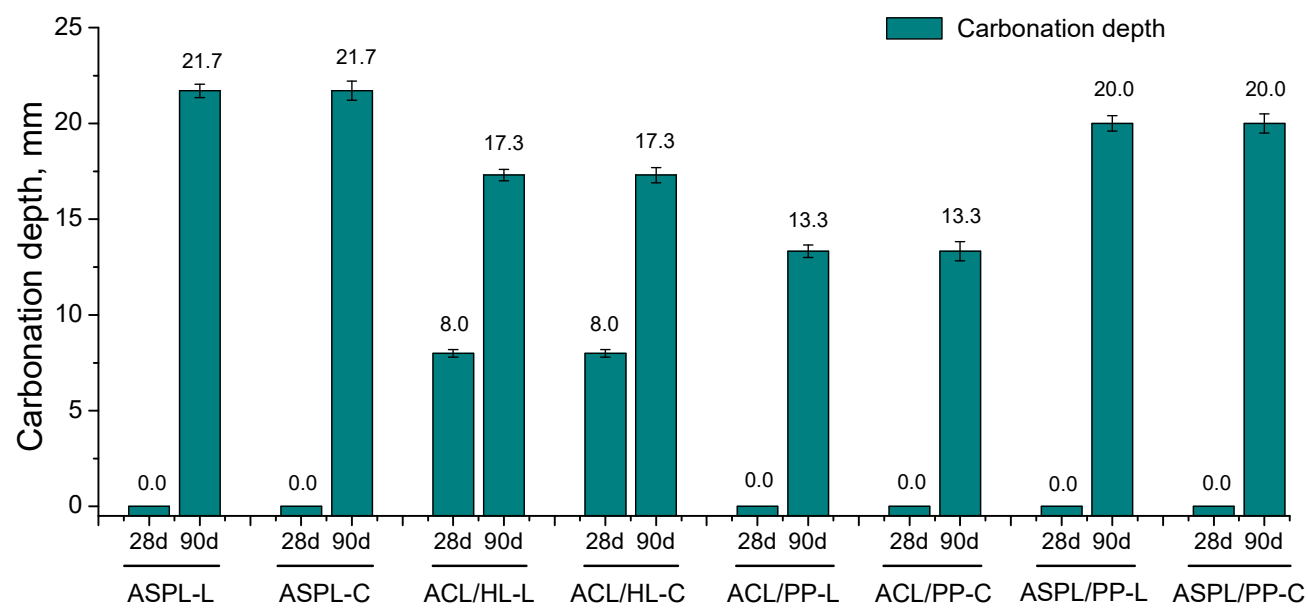

Figure 10. Carbonation front depths at 28 and 90 hardening days observed for the studied mortars.

\section{Discussion}

Regarding the porosity results, they were overall in keeping with those obtained for the bulk density, showing higher porosities the mortars with lower bulk densities (ASPL and ASPL series), whereas for the series with lower porosity values, greater bulk densities were noted (ACL/HL and ACL/PP series). These results would agree with other authors [16], which pointed out that mortars with standard lime putties generally showed greater values of open porosity and smaller bulk densities. Furthermore, several authors [14] have noted that the aggregate used in lime mortars has an influence on their porosity, especially when aerial lime is used. Then, the higher bulk density and lower porosity obtained for the studied mortars with aerial lime and crushed rock powder would 
indicate a beneficial effect when crushed rock powder is combined with this type of lime. Finally, the porosity values obtained in this research are in keeping with those noted by Gomes [40], who referred to porosity values between $17 \%$ and $29.5 \%$ for mortars applied to the exterior plaster of old buildings, and with those obtained by Bandeira [42] and Pavão [39], who reported values of this parameter to be between 24 and 32.5\%.

If the results of porosity, discussed in the previous subsection, are compared with the results of the coefficient of water absorption by capillarity, it can be observed that the mortars with higher global porosities (ASPL and ASPL/PP series) showed lower capillarity coefficients, whereas those with lower global porosities (ACL/HL and ACL/PP series) had higher capillarity coefficients. This could be explained in relation to the different pore size distributions present in the microstructure of the mortar series analyzed. The previous comparison between the results of global porosity and the coefficient of water absorption by capillarity would suggest the possible prevailing presence of pores with higher diameters for lime putty mortars (ASPL and ASPL/PP series), which would make more difficult the absorption of water by capillarity due to their lower pore surface, despite having a higher global porosity. On the other hand, the mortars with aerial lime (ACL/HL and ACL/PP series) would have a finer microstructure, with a predominance of pores with smaller sizes, which would produce a higher global pore surface in the material, through which was produced the water absorption by capillarity phenomenon. This would explain that these ACL/HL and ACL/PP mortars showed greater capillarity coefficients in spite of having less global porosity.

These different pore size distributions of the mortars, depending on their composition suggested by capillarity absorption results, would coincide with other authors [15] who indicated that mortars with lime putty presented a bimodal pore size distribution, with two predominant families of pores with 0.04 and $16.8 \mu \mathrm{m}$ radius, while lime-powder mortars showed a unimodal distribution with the most common pore diameters at $0.6 \mu \mathrm{m}$. Then, the higher water absorption by capillarity observed in this work for the mortars with aerial lime could be related to the previously mentioned unimodal pore size distribution, with a relatively small average pore size $(0.6 \mu \mathrm{m})$, which would facilitate the penetration of water by capillarity in the microstructure of the material. In addition to this, it has been reported in other works that the use of aerial lime binders could reduce the water resistance of the materials [10] and that the combination of aerial and hydraulic limes in blended mortars could produce an increase in water capillarity [11], which would also agree with the results obtained in this work. Lastly, the values of the coefficient of water absorption by capillarity noted for the tested mortars were also in keeping with those obtained in other studies [39,40,43], which reported values of this coefficient between 0.15 and $0.31 \mathrm{~kg} /\left(\mathrm{m}^{2} \mathrm{~s}^{1 / 2}\right)$ for mortars applied as plasters of outer elements of old buildings.

With respect to the results of the percentages of water absorption by immersion, they agreed with those pointed out by Gomes [40], who reported values of this parameter between 8.5 and $20 \%$ for mortars applied as external plasters of old buildings. In addition to this, the percentages of water absorption by immersion noted here would be also consistent with the results obtained by Mendonça [44], who reported values of this parameter in the range from $11.5 \%$ to $12 \%$ for mortars for the same application.

In general, the results of porosity, already discussed, were in keeping with the percentages of water absorption by immersion. Mortars with lime putty (ASPL and ASPL/PP series) showed higher porosities and higher percentages of water absorption by immersion, while mortars with aerial lime (ACL/HL and ACL/PP series) overall presented lower values of both parameters.

However, comparing the results of the coefficient of water absorption by capillarity with those for the percentages of water absorption by immersion, there was no clear coincidence between them, because the lime putty mortars (ASPL and ASPL/PP series) with a lower coefficient of capillarity showed a higher percentage of absorption by immersion, whereas the opposite was noted for mortars with aerial lime in the binder (ACL/HL and ACL/PP series). Initially, it would be expected that specimens with a higher coefficient 
of capillarity also had a higher percentage of absorption by immersion. Nevertheless, the results obtained could be explained in terms of the pore size distribution in the microstructure of the lime mortars. As has been explained in the discussion of results obtained for the coefficient of capillarity, they would suggest the possible higher proportion of pores with higher sizes in the lime putty mortars (ASPL and ASPL/PP series), making more difficult the penetration of water by capillarity, due to the lower global pore surface in the microstructure. For the mortars with aerial lime (ACL/HL and ACL/PP series), the results of capillarity coefficient would indicate a finer porous network, with a higher proportion of pores with smaller sizes, which would increase the pore surface, making easier the development of water absorption by capillarity phenomenon.

Regarding the percentage of absorption by immersion, the arguments previously explained are compatible with the results obtained here for this parameter. The phenomena of water absorption by capillarity and by immersion are different. In the case of a finer microstructure, with a higher proportion of pores with small sizes, the water absorption process by immersion would be more difficult due to the greater tortuosity of the pore network, which slows down the penetration of water under pressure inside it. This reasoning would explain the lower percentages of absorption by immersion noted for aerial lime mortars (ACL/HL and ACL/PP series). On the contrary, for a material with a coarser pore structure, with a higher proportion of pores with great sizes, the water absorption by immersion would be easier, producing a faster penetration of water under the pressure due to immersion. This could justify the higher percentages of absorption by immersion observed for lime putty mortars (ASPL and ASPL/PP series).

As has also been discussed for the results of water absorption by capillarity, other authors [15] reported differences in the pore size distribution of mortars with aerial lime and lime putty. On the one hand, mortars with lime putty usually showed a bimodal pore size distribution, with two pore families with 0.04 and $16.8 \mu \mathrm{m}$ diameters [15]. On the other hand, mortars with lime powder usually presented a unimodal distribution with the most frequent pore size at $0.6 \mu \mathrm{m}$. In view of that, the higher water absorption by immersion noted in this research for the lime putty mortars could be explained in relation to the abovementioned presence of a pore family with relatively high diameter, such as $16.8 \mu \mathrm{m}$ [15], which would make the penetration of water by immersion easier in pore network of the material. This would support the reasoning previously explained for justifying the higher percentages of absorption by immersion observed for lime putty mortars in this research.

In relation to the results obtained for the drying kinetic assessment, they were consistent with those obtained by other authors $[39,45]$ for mortars applied as outer plasters of old buildings. Finally, the carbonation depth results were generally in agreement with those obtained for porosity. The lime putty mortars were more porous; therefore, this would produce that they were more affected by carbonation, as confirmed by the results of carbonation depths observed. On the other hand, the less porosity observed for series with aerial lime in the binder would make more difficult the advance of the carbonation front, as suggested by the lower carbonation depths observed for these mortars.

\section{Conclusions}

In view of the results obtained, the fresh properties (consistency by using the flow table and water retentivity) were very similar for all the lime mortars studied. In addition, slight differences between both curing conditions have been noted regarding the results of the hardened properties of the different lime mortars analyzed.

Regarding the durability-related parameters of the lime mortars studied, the values obtained for them would be adequate for being applied as external masonry coatings and plasters in the restoration of old buildings, according to other authors.

However, several differences have been observed between the analyzed mortars series. Lime putty mortars (ASPL and ASPL/PP series) showed lower bulk densities, higher global porosities, lower coefficients of water absorption by capillarity, higher percentages 
of water absorption by immersion, lower percentages of evaporated water after long-term drying, and higher carbonation depths, in comparison with mortars that incorporated aerial lime (ACL/HL and ACL/PP series).

Furthermore, the results of water absorption by capillarity and by immersion would suggest the presence of a greater proportion of pores with higher diameters in the microstructure of lime putty mortars, whereas mortars with aerial lime would have a finer microstructure, with a predominance of pores with smaller sizes.

Finally, the incorporation of crushed rock powder as aggregate produced an increase in the bulk density of the lime mortars.

Author Contributions: Conceptualization, F.G.B. and M.d.L.B.; methodology, F.G.B. and M.d.L.B.; investigation, C.M., F.G.B., L.P., M.d.L.B., and J.M.O.; data curation, C.M., F.G.B., M.d.L.B., and J.M.O.; writing-original draft preparation, F.G.B. and J.M.O.; writing-review and editing, L.P. and M.d.L.B.; supervision, F.G.B. and M.d.L.B.; funding acquisition, F.G.B. and J.M.O. All authors have read and agreed to the published version of the manuscript. This research includes part of the work developed along the research stay of José Marcos Ortega in the ISISE-Functional Performance research group at Department of Civil Engineering of University of Coimbra between May and July 2019, under the supervision of Fernando G. Branco.

Funding: This work was partially funded through FCT-Foundation for Science and Technology, IP, within the scope of the R\&D Unit Institute for sustainability and innovation in structural engineeringISISE (UIDP/04029/2020), and by the ERDF through the COMPETE 2020 program, Portugal 2020, under the project POCI-01-0247-FEDER-033990 (iNBRail). The APC for publishing this article was funded by the Conselleria de Educación, Investigación, Cultura y Deporte (at present renamed as Conselleria de Innovación, Universidades, Ciencia y Sociedad Digital) de la Generalitat Valenciana (Spain) (grant code GV/2019/070). The research stay of José Marcos Ortega at the University of Coimbra was financially supported in part by the University of Alicante.

Institutional Review Board Statement: Not applicable.

Informed Consent Statement: Not applicable.

Data Availability Statement: Not applicable.

Conflicts of Interest: The authors declare no conflict of interest.

\section{References}

1. Coelho, A.Z.G.; Torgal, F.P.; Jalali, S. A Cal na Construção; TecMinho: Guimaraes, Portugal, 2009; ISBN 978-972-99179-8-1.

2. Veiga, R. Air lime mortars: What else do we need to know to apply them in conservation and rehabilitation interventions? A review. Constr. Build. Mater. 2017, 157, 132-140. [CrossRef]

3. Marrero, M.; Rivero-Camacho, C.; Alba-Rodríguez, M.D. What are we discarding during the life cycle of a building? Case studies of social housing in Andalusia, Spain. Waste Manag. 2020, 102, 391-403. [CrossRef] [PubMed]

4. Ighravwe, D.E.; Oke, S.A. A multi-criteria decision-making framework for selecting a suitable maintenance strategy for public buildings using sustainability criteria. J. Build. Eng. 2019, 24, 100753. [CrossRef]

5. Qualharini, E.L.; Oscar, L.H.C.; Silva, M.R.D. Rehabilitation of buildings as an alternative to sustainability in Brazilian constructions. Open Eng. 2019, 9, 139-143. [CrossRef]

6. Veiga, R.; Santos Silva, A. Mortars. In Long-Term Performance and Durability of Masonry Structures; Ghiassi, B., Lourenço, P.B., Eds.; Woodhead Publishing Series in Civil and Structural Engineering: Duxford, UK, 2019; pp. 169-208. ISBN 978-0-08-102110-1.

7. Moropoulou, A.; Maravelaki-Kalaitzaki, P.; Borboudakis, M.; Bakolas, A.; Michailidis, P.; Chronopoulos, M. Historic mortars technologies in Crete and guidelines for compatible restoration mortars. In PACT, Revue du Groupe Europeen d'Etudes Pour les Techniques Physiques, Chimiches, Biologiques et Mathematiques Applique's a l'Archeologie, Compatible Materials for the Protection of European Cultural Heritage; G Biscontin, A., Moropoulou, M., Erdik, J.D.R., Eds.; Technical Chamber of Greece: Athens, Greece, 1998; Volume 55, pp. 55-72.

8. Maravelaki-Kalaitzaki, P.; Bakolas, A.; Karatasios, I.; Kilikoglou, V. Hydraulic lime mortars for the restoration of historic masonry in Crete. Cem. Concr. Res. 2005, 35, 1577-1586. [CrossRef]

9. Silva, B.A.; Ferreira Pinto, A.P.; Gomes, A. Natural hydraulic lime versus cement for blended lime mortars for restoration works. Constr. Build. Mater. 2015, 94, 346-360. [CrossRef]

10. Gulbe, L.; Vitina, I.; Setina, J. The Influence of Cement on Properties of Lime Mortars. Procedia Eng. 2017, 172, 325-332. [CrossRef]

11. Silva, B.A.; Ferreira Pinto, A.P.; Gomes, A. Influence of natural hydraulic lime content on the properties of aerial lime-based mortars. Constr. Build. Mater. 2014, 72, 208-218. [CrossRef] 
12. Garijo, L.; Zhang, X.; Ruiz, G.; Ortega, J.J. Age effect on the mechanical properties of natural hydraulic and aerial lime mortars. Constr. Build. Mater. 2020, 236, 117573. [CrossRef]

13. Aalil, I.; Badreddine, D.; Beck, K.; Brunetaud, X.; Cherkaoui, K.; Chaaba, A.; Al-Mukhtar, M. Valorization of crushed bricks in lime-based mortars. Constr. Build. Mater. 2019, 226, 555-563. [CrossRef]

14. Santos, A.R.; Veiga, M.D.R.; Santos Silva, A.; de Brito, J.; Álvarez, J.I. Evolution of the microstructure of lime based mortars and influence on the mechanical behaviour: The role of the aggregates. Constr. Build. Mater. 2018, 187, 907-922. [CrossRef]

15. Aggelakopoulou, E.; Bakolas, A.; Moropoulou, A. Lime putty versus hydrated lime powder: Physicochemical and mechanical characteristics of lime based mortars. Constr. Build. Mater. 2019, 225, 633-641. [CrossRef]

16. Faria, P.; Henriques, F.; Rato, V. Comparative evaluation of lime mortars for architectural conservation. J. Cult. Herit. 2008, 9, 338-346. [CrossRef]

17. Grilo, J.; Faria, P.; Veiga, R.; Santos Silva, A.; Silva, V.; Velosa, A. New natural hydraulic lime mortars-Physical and microstructural properties in different curing conditions. Constr. Build. Mater. 2014, 54, 378-384. [CrossRef]

18. Grilo, J.; Santos Silva, A.; Faria, P.; Gameiro, A.; Veiga, R.; Velosa, A. Mechanical and mineralogical properties of natural hydraulic lime-metakaolin mortars in different curing conditions. Constr. Build. Mater. 2014, 51, 287-294. [CrossRef]

19. Faria, P.; Silva, V.; Grilo, J.; Carneiro, J.; Branco, T.; Mergulhão, D.; Antunes, R. Argamassas compatíveis com alvenarias históricas com base em cal hidráulica natural. In CIRea2012-Conferência Internacional sobre Reabilitação de Estruturas Antigas de Alvenaria; Universidade Nova de Lisboa: Lisboa, Portugal, 2012; pp. 29-38.

20. Matias, G.; Faria, P.; Torres, I. Lime mortars with heat treated clays and ceramic waste: A review. Constr. Build. Mater. 2014, 73, 125-136. [CrossRef]

21. Gameiro, A.; Santos Silva, A.; Faria, P.; Grilo, J.; Branco, T.; Veiga, R.; Velosa, A. Physical and chemical assessment of limemetakaolin mortars: Influence of binder:aggregate ratio. Cem. Concr. Compos. 2014, 45, 264-271. [CrossRef]

22. Instituto Português da Qualidade NP EN 459-1. Cal De Construção-Parte 1: Definições, Especificações e Critérios de Conformidade; Instituto Português da Qualidade: Lisboa, Portugal, 2015.

23. Instituto Português da Qualidade NP EN 933-1. Ensaios das Propriedades Geométricas Dos Agregados—Parte 1: Análise Granulométrica, Método da Peneiração; Instituto Português da Qualidade: Lisboa, Portugal, 2014.

24. Instituto Português da Qualidade NP EN 1097-6. Ensaios Das Propriedades Mecânicas e Físicas Dos Agregados, Parte 6: Determinação da Massa Volúmica E da Absorção de Água; Instituto Português da Qualidade: Lisboa, Portugal, 2016.

25. Instituto Português da Qualidade NP EN 1097-3. Ensaios Das Propriedades Mecânicas e Físicas Dos Agregados, Parte 3: Determinação da Baridade E Do Volume de Vazios; Instituto Português da Qualidade: Lisboa, Portugal, 2002.

26. European Committee for Standardization EN 1015-2. Methods of Test for Mortar for Masonry_Part 2: Bulk Sampling of Mortars and Preparation of Test Mortars; European Committee for Standardization: Brussels, Belgium, 1999.

27. European Committee for Standardization EN 1015-11. Methods of Test for Mortar for Masonry-Part 11: Determination of Flexural and Compressive Strength of Hardened Mortar; European Committee for Standardization: Brussels, Belgium, 1999.

28. Barreto, M.C.C.L. Durabilidade da Argamassas de Cal Aérea e Bastardas Face à Acção de Sais Solúveis. Dissertação para obtenção Do Grau de Mestre em Engenharia Civil—Construção; Universidade Nova de Lisboa: Lisbon, Portugal, 2010.

29. European Committee for Standardization EN 1015-3. Methods of Test for Mortar for Masonry_Part 3: Determination of Consistence of Fresh Mortar (by Flow Table); European Committee for Standardization: Brussels, Belgium, 2000.

30. European Committee for Standardization EN 1015-8. Methods of Test for Mortar Masonry—Part 8: Determination of Water Retentivity of Fresh Mortar; European Committee for Standardization: Brussels, Belgium, 1999.

31. Santos, D.A.F. dos A Influência das Condições de Cura Nas Propriedades das Argamassas De Cal Para Revestimentos Antigos. Dissertação para obtenção do grau de Mestre em Engenharia Civil na Área de Especialização de Edificações; Instituto Superior de Engenharia de Lisboa: Lisbon, Portugal, 2014.

32. Ortega, J.M.; Ferrandiz, V.; Antón, C.; Climent, M.A.; Sánchez, I. Influence of curing conditions on the mechanical properties and durability of cement mortars. In Materials Characterisation IV: Computational Methods and Experiments; Mammoli, A.A., Brebbia, C.A., Eds.; WIT Press: Southampton, UK, 2009; pp. 381-392.

33. Instituto Português da Qualidade NP EN 1936. Métodos de Ensaio Para Pedra Natural_Determinação das Massas Volúmicas Real e Aparente e das Porosidades Total e Aberta; Instituto Português da Qualidade: Lisboa, Portugal, 2008.

34. Ortega, J.M.; Sánchez, I.; Climent, M.A. Influence of environmental conditions on durability of slag cement mortars. In Proceedings of the 2nd International Conference on Sustainable Construction Materials and Technologies, Ancona, Italy, 28-30 June 2010.

35. Santos, T.; Faria, P.; Silva, V. Can an earth plaster be efficient when applied on different masonries? J. Build. Eng. 2019, 23, 314-323. [CrossRef]

36. Columbu, S.; Sitzia, F.; Ennas, G. The ancient pozzolanic mortars and concretes of Heliocaminus baths in Hadrian's Villa (Tivoli, Italy). Archaeol. Anthropol. Sci. 2017, 9, 523-553. [CrossRef]

37. European Committee for Standardization EN 1015-18. Methods of Test for Mortar for Masonry-Part 18: Determination of Water Absorption Coefficient Due to Capillary Action of Hardened Mortar; European Committee for Standardization: Brussels, Belgium, 2002.

38. Laboratorio Nacional de Engenharia Civil Especificações LNEC E 394. Betões—Determinação da Absorção de Água por Imersão; Laboratorio Nacional de Engenharia Civil Especificações: Lisboa, Portugal, 1993.

39. Pavão, J.M. Estudo da Influência da Dosagem de Ligante No Desempenho de Rebocos Para Edifícios Antigos. Master's Thesis, Universidade Técnica de Lisboa, Lisbon, Portugal, 2010. 
40. Gomes, F.A.C.M. Argamassas Pré-Doseadas Para rebocos de Edificios Antigos. Master's Thesis, Universidade Técnica de Lisboa, Lisbon, Portugal, 2009.

41. RILEM. CPC-18 Measurement of hardened concrete carbonation depth. Mater. Constr. 1988, 21, 453-455. [CrossRef]

42. Bandeira, A.F.D. Caracterização de Argamassas de Cal Aérea e de Cal Hidráulica Natural Com Metacaulino. Evolução com a idade. Master's Thesis, Universidade Nova de Lisboa, Lisbon, Portugal, 2012.

43. Algravio, M.P.R.P. Influência da Razão Água/Ligante Nas Características das Argamassas de Cal Aérea Para Rebocos de Edificios Antigos. Master's Thesis, Universidade Técnica de Lisboa, Lisbon, Portugal, 2010.

44. Mendonça, B.d.V. Estudo do Desempenho das Argamassas Hidráulicas-Influência do Ligante. Master's Thesis, Universidade Técnica de Lisboa, Lisbon, Portugal, 2007.

45. Agostinho, C.S.A. Estudo da Evolução do Desempenho No Tempo de Argamassas de Cal Aérea. Master's Thesis, Universidade Técnica de Lisboa, Lisbon, Portugal, 2008. 